\title{
Research work on Working Capital
}

\author{
Magdalene Peter, R. Ravimohan, S.Venkatraman
}

\begin{abstract}
Working capital Management in the example units was wasteful. A lopsided interest in current resource in connection to deal brought about declining working capital turnover proportion. The organization did not pursue any reliable approach regarding speculation and financing of working capital. Despite the fact that there existed numerous chances to utilize exchanging on value and supporting for proper administration of working capital, the organization never utilized the equivalent. Having examined working capital as far as present proportion, fast proportion, working capital turnover proportion, stock turnover proportion, account holder's turnover proportion and normal gathering period, the investigation uncovered that the organization neglected to oversee stock proficiently which thus has brought about lower productivity
\end{abstract}

\section{INTRODUCTION}

The term working capital is usually utilized for the capital required for everyday working in a business concern, for example, for acquiring crude material, for gathering everyday use on pay rates, compensation, rents rates, publicizing and so forth. However, there are much difference among different monetary specialists (Financiers, bookkeepers, agents and business analysts) with regards to the precise significance of the term working capital. [7],[ 9] ,[11]

\section{RESEARCH DESIGN}

Research is an organized activity focused on specific objectives with the support of data collection involving tools for analysis driving logically sound inference. Research designs are the framework or plan a study that guides the collection and analysis of data. The function of research is to ensure that required the data collected or accurate and economically. The research is analytical in nature[13], [15] ,[ 17]
TABLE NO.4.10

WORKING CAPITAL TURNOVER RATIO (In Rupees)

\begin{tabular}{r|l|l|l|}
\hline YEAR & $\begin{array}{l}\text { CURRENT } \\
\text { ASSETS }\end{array}$ & CURRENTL LABILITIES & RATIO \\
\hline $2012-2013$ & 94466423 & 12557888 & 7.52 \\
\hline $2013-2014$ & 13249222 & 7986124 & 0.16 \\
\hline $2014-2015$ & 19162921 & 1085740 & 17.64 \\
\hline $2015-2016$ & 18442077 & 2759015 & 6.68 \\
\hline $2016-2017$ & 24904265 & 966483 & 25.76 \\
\hline
\end{tabular}

CHART NO. 4.10

JRAPHICAL REPRESENTATION OF CHANGE OF DIRECTION OF WORKING CAPITAL TURNOVER RATIO

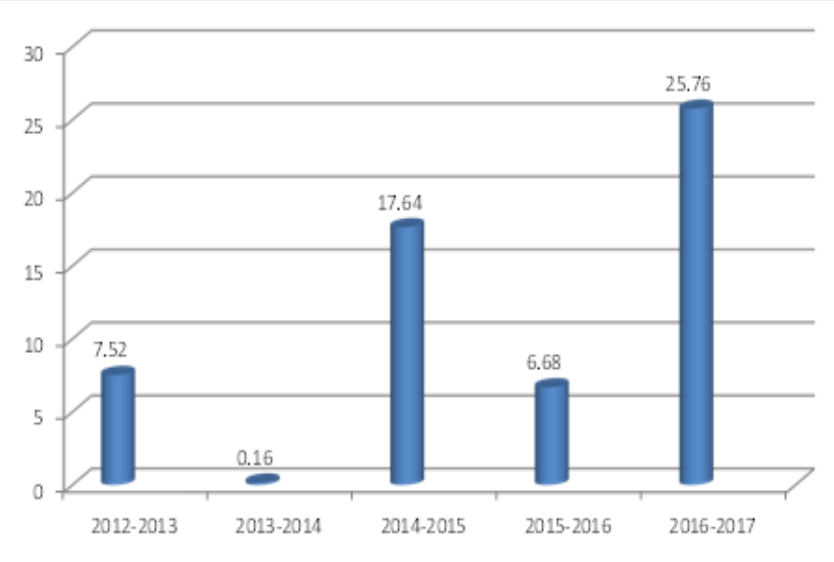

NFERENCE

The above table exhibits that the working capital turnover ratio is shanging continuously and it was low 0.16 during the period of 2013-2014

\begin{tabular}{|c|c|c|c|}
\hline \multicolumn{4}{|c|}{ TABLEN0.4.1 } \\
\hline \multicolumn{4}{|c|}{ CURRENT RATIO (In Rupees) } \\
\hline \multicolumn{4}{|c|}{ Current Liabilities } \\
\hline YEAR & CURRENT ASSETS & CURRENTLIABILITIES & RATIO \\
\hline $2012-2013$ & 18335520 & 5797632 & 3.16 \\
\hline $2013-2014$ & 14636269 & 6650145 & 2.20 \\
\hline $2014-2015$ & 9126380 & 8040640 & 1.13 \\
\hline $2015-2016$ & 5323215 & 2564200 & 2.07 \\
\hline $2016-2017$ & 3769243 & 2802760 & 1.34 \\
\hline
\end{tabular}

Revised Manuscript Received on July 22, 2019

Ms Magdalene Peter , Assistant Professor, Department of MBA,Bharath institute of Higher Education \& Research,Tamilnadu,India

Mr. R. Ravimohan, Assistant Professor, Department of MBA,Bharath institute of Higher Education \& Research,Tamilnadu,IndiaEmail: rajmohanravimohan@gmail.com

S.Venkatraman, Department of Civil Engg,,Bharath institute of Higher Education \& Research,Tamilnadu,India Email: mailmagik@yahoo.com 


\section{Research work on Working Capital}

CHART NO. 4.1

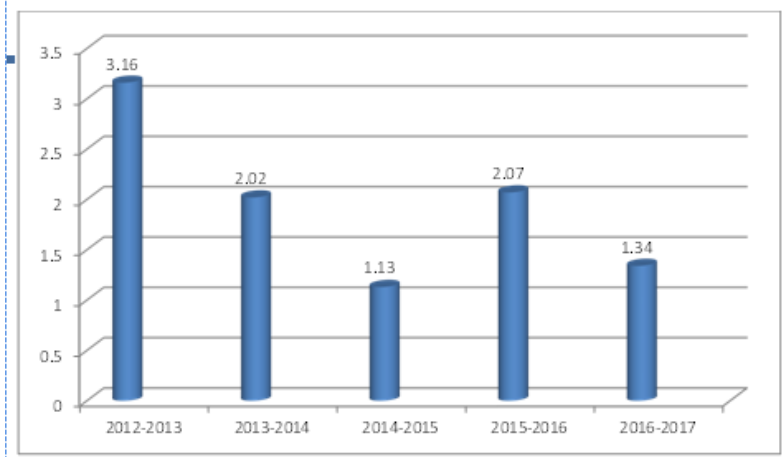

INFERENCE

From the above table one can understand that the current ratio is changing continuously and it was low 1.13 during the period of 2014-2015 and increase to 3.16 during the period of 2012

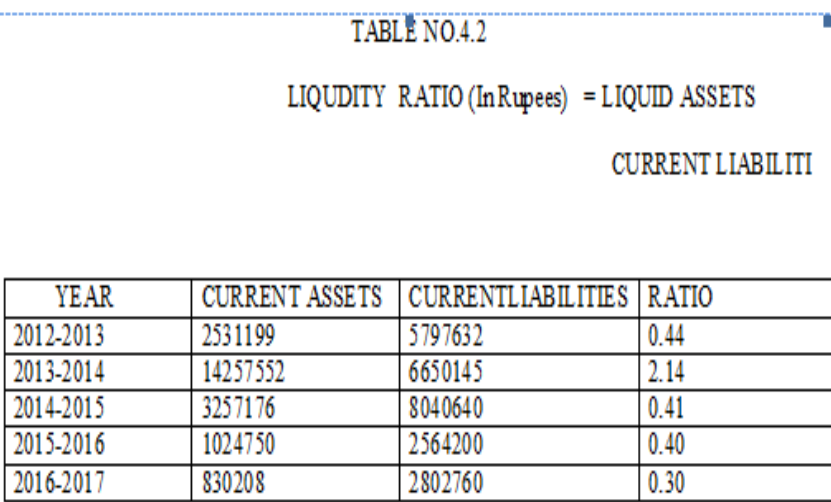

TABLE NO. 4.3

ABSOLUTE LIQUD RATIO (In Rupees) $=$ CASH \&BANK BALANCE

CURRENT LLABILITIES

\begin{tabular}{|l|l|l|l|}
\hline \multicolumn{1}{|c|}{ YEAR } & CURRENT ASSETS & CURRENTLIABILITIES & RATIO \\
\hline $2012-2013$ & 17332292 & 5797632 & 2.98 \\
\hline $2013-2014$ & 13574946 & 6650145 & 2.04 \\
\hline $2014-2015$ & 8638025 & 8040640 & 1.07 \\
\hline $2015-2016$ & 4913050 & 2564200 & 1.91 \\
\hline $2016-2017$ & 2984728 & 2802760 & 1.06 \\
\hline
\end{tabular}

GRAPHICAL REPRESENTATION OF CHANGE OF DIRECTION OF CURRENT RATIO 2013. In above shows that in of 2014-2015 the current ratio.

CHART NO. 4.2

GRAPHICAL REPRESENTATION OF CHANGE OF DIRECTION OF LIQUIDITY RATIO

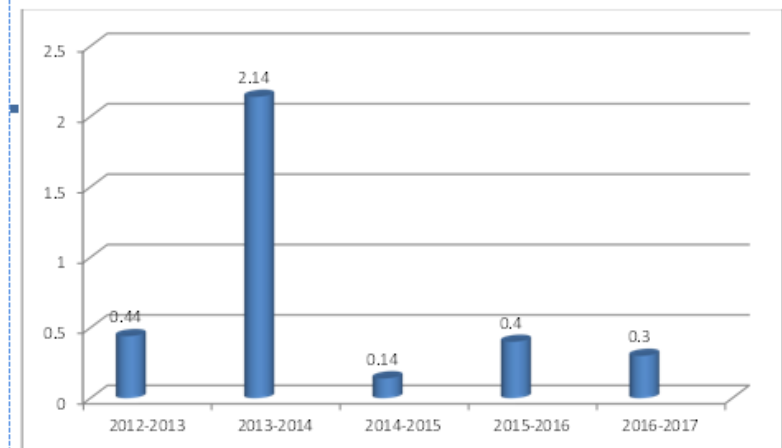

INFERENCE

From the above table represent that the liquid ratio is changing continuously and it was low 0.30 during the period of 2016-2017 and it increase to 2.14 during the period of 2013-2014.A we analyzed the ratio we can see that of 2013-2014 the liquidratio is very high because of high volume local sales.

GRAPHICAL REPRESENTATION OF CHANGE OF DIRECTION OF ABSOLUTE LIQUID RATIO

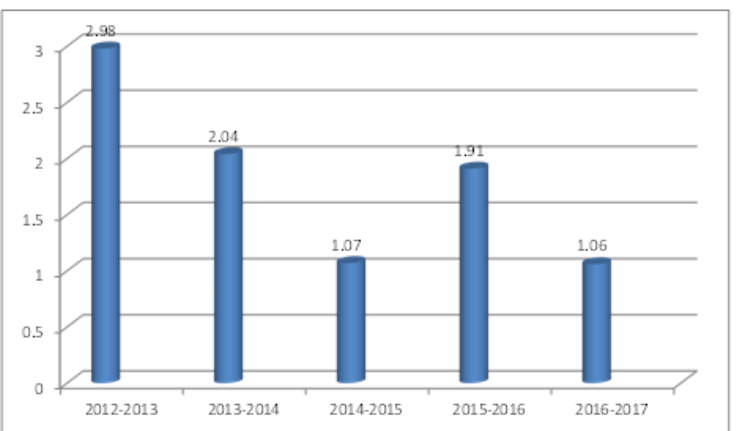

INFERENCE

From the above table indicates that the absolute liquid ratio is changing continuously and it was low 1.06 during the period of 2016-2017 andit increase to 2.98 during the period of 2012 2013.

\begin{tabular}{|l|l|l|l|}
\hline \multicolumn{1}{|c|}{ YEAR } & CURRENT ASSETS & CURRENTL LABILITIES & RATIO \\
\hline $2012-2013$ & 14149016 & 8141622 & 1.74 \\
\hline $2013-2014$ & 9438667 & 6193427 & 1.52 \\
\hline $2014-2015$ & 5485825 & 2208803 & 2.48 \\
\hline $2015-2016$ & 6396102 & 3119080 & 2.05 \\
\hline $2016-2017$ & 6773896 & 3494580 & 1.93 \\
\hline
\end{tabular}

GRAPHICAL REPRESENTATION OF CHANGE OF DIRECTION OF DEBIT EQUITY RATIO

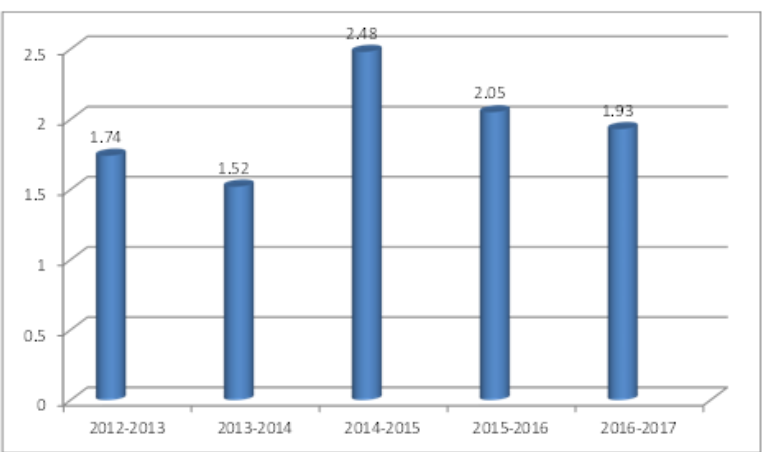

Published By:

Blue Eyes Intelligence Engineering 


\begin{tabular}{|l|l|l|l|}
\hline \multicolumn{1}{|c|}{ YEAR } & CURRENT ASSETS & CURRENTL IABILITIES & RATIO \\
\hline $2012-2013$ & 3126797 & 94466423 & 3.309 \\
\hline $2013-2014$ & 636422 & 13249222 & 4.8 \\
\hline $2014-2015$ & 575495 & 19162921 & 3 \\
\hline $2015-2016$ & 391952 & 18442077 & 2.12 \\
\hline $2016-2017$ & 2854140 & 24904265 & 11.4 \\
\hline
\end{tabular}

CHART NO. 4.5

GRAPHICAL REPRESENTATION OF CHANGE OF DIRECTION OF GROSS PROFIT RATIO

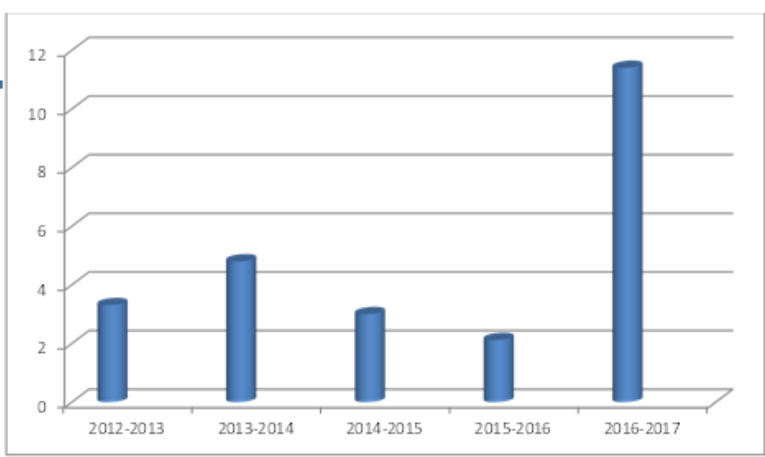

INFERENCE

From the above table one can under stand that the gross profit ratio is changing continuously and it was low 2.12 during the period of 2015-2016 and it increase to 3.309 during the period of 2012-2013.As we compare the gross profit ratio of every year it can be noticed that in 2016-2017 it is very high because of high ex port sales.

NET PROFIT RATIO (In Rupees) = NET PROFIT AFTER TAX

NET SALES

\begin{tabular}{|l|l|l|l|}
\hline \multicolumn{1}{|c|}{ YEAR } & CURRENT ASSETS & CURRENTLIABILITIES & RATI0 \\
\hline $2012-2013$ & 449387 & 5797632 & 3.3 \\
\hline $2013-2014$ & 319236 & 6650145 & 1.66 \\
\hline $2014-2015$ & 50277 & 8040640 & 2.72 \\
\hline $2015-2016$ & 307860 & 2564200 & 1.23 \\
\hline $2016-2017$ & 3769243 & 2802760 & 1.1 \\
\hline
\end{tabular}

CHART NO. 4.6

GRAPHICAL REPRESENTATION OF CHANGE OF DIRECTION OF NET PROFIT RATIO

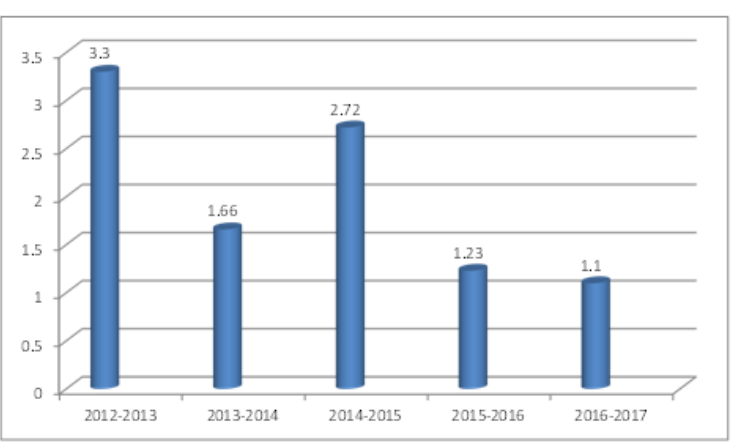

OPERATING RATIO (InRupees) =OPERATING EXPENSES

NET SALES

\begin{tabular}{|l|l|l|l|}
\hline \multicolumn{1}{|c|}{ YEAR } & CURRENT ASSETS & CURRENTLIABILITES & RATIO \\
\hline $2012-2013$ & 92972580 & 94466432 & 98.41 \\
\hline $2013-2014$ & 13618484 & 13249222 & 102.78 \\
\hline $2014-2015$ & 19763084 & 19162921 & 103.13 \\
\hline $2015-2016$ & 19225825 & 18442077 & 104.24 \\
\hline $2016-2017$ & 23506075 & 24904265 & 94.3 \\
\hline
\end{tabular}

Published By:

Blue Eyes Intelligence Engineering \& Sciences Publication
GRAPHICAL REPRESENTATION OF CHANGE OF DIRECTION OF OPERATING RATIO

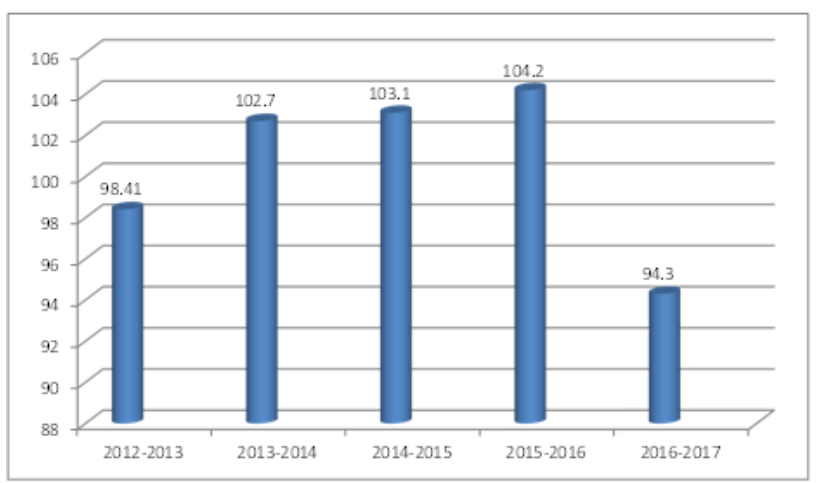

INFERENCE

From the above table indicates that the oper ating ratio is changing continuously and it was low94.3 during the period of 2016-2017 and it increase to 104.24 during the period of 20152016 the local purchase was low so the operating ratio was also low compared to other year.

\section{TABLE N0.4.8}

\section{CAPITAL TURNOVER RATIO (InRuppes) =REVENUE}

AVERAGE W.CP

\begin{tabular}{|l|l|l|l}
\hline \multicolumn{1}{|c|}{ YEAR } & CURRENT ASSETS & CURRENTLLABLITES & RATIO \\
\hline $2012-2013$ & 94466423 & 13576835 & 6.95 \\
\hline $2013-2014$ & 13249222 & 9016387 & 1.469 \\
\hline $2014-2015$ & 19162221 & 4976206 & 3.85 \\
\hline $2015-2016$ & 1844077 & 5782900 & 0.31 \\
\hline $2016-2017$ & 24904265 & 11149563 & 2.23 \\
\hline
\end{tabular}

CHART NO. 4.8

GRAPHICAL REPRESENTATION OF CHANGE OF DIRECTION OF CAPITAI TURNOVER RATIO

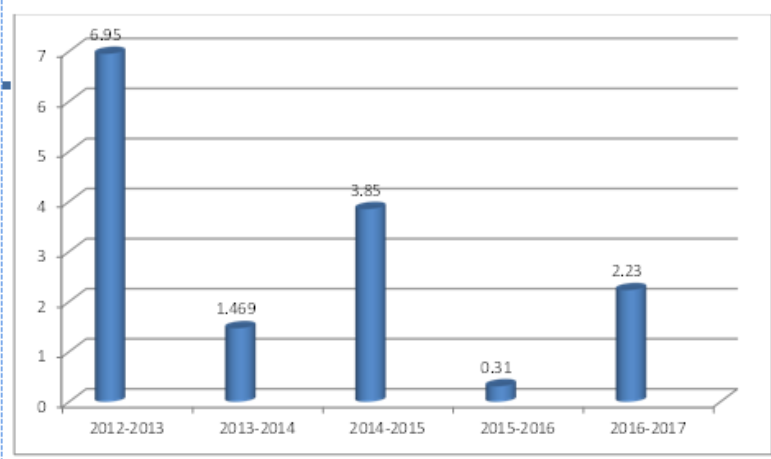

INFERENCE

From the above represent that the capital turnover ratio is changing continuously and it was low 0.31 during the period of 2015-2016 and it increase to 6.95 during the period of 2012-2013. The above table clearly seen that due to the un stability of local sales export sales delayed paym ent and government activities the capital turnover was not stable. 
STOCK TURNOVER RATIO (InRLupees) = COST OF GOOD SOLD

AVERAGE NVENTORNG

\begin{tabular}{|l|l|l|l|}
\hline \multicolumn{1}{|c|}{ YEAR } & CURRENT ASSETS & CURRENTLLABIITIES & RATIO \\
\hline $2012-2013$ & 94466423 & 3495598 & 27.2 \\
\hline $2013-2014$ & 13249222 & 11091156 & 11.94 \\
\hline $2014-2015$ & 19162921 & 714462 & 26.82 \\
\hline $2015-2016$ & 1844077 & 364030 & 5.06 \\
\hline $2016-2017$ & 249044265 & 449940 & 55.35 \\
\hline
\end{tabular}

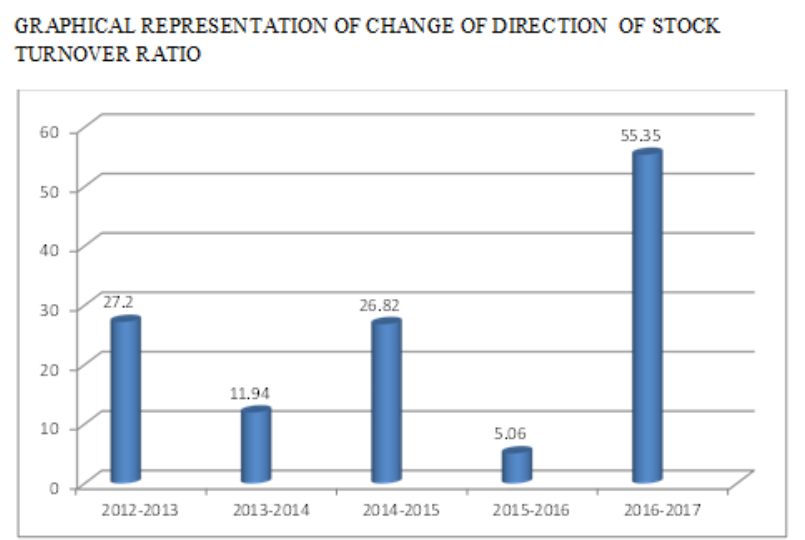

SCHEDULE OF CHANGE IN WORKING CAPIT AL 2015-2016 to 2016-2017

(IN Rup ees)

\begin{tabular}{|l|l|l|l|l|}
\hline Particular & $\mathbf{2 0 1 5 - 2 0 1 6}$ & $\mathbf{2 0 1 6 - 2 0 1 7}$ & INCRE ASE & DE CRE ASE \\
\hline CURRE NT ASSETS & & & & \\
\hline Cash \& Bank & $10,24,750$ & $8,30,208$ & & $1,94,542$ \\
\hline S undry Deb tors & $38,88,300$ & $21,54,520$ & & $17,33,780$ \\
\hline Advance Tax \& IDS & $2,84,745$ & $4,59,995$ & $1,75,250$ & \\
\hline Closing Stock & $1,25,420$ & $3,24,520$ & $1,99,100$ & \\
\hline T Or AL ASSE TS(A) & $\mathbf{5 3 , 2 3 , 2 1 5}$ & $\mathbf{3 7 , 6 9 , 2 4 3}$ & & \\
\hline $\begin{array}{l}\text { CURRE NT } \\
\text { L IABILITIE S }\end{array}$ & & & & \\
\hline Current liabilities & $\mathbf{2 5 , 6 4 , 2 0 0}$ & $\mathbf{2 8 , 0 2 , 7 6 0}$ & & $\mathbf{2 , 3 8 , 5 6 0}$ \\
\hline $\begin{array}{l}\text { T Or AL } \\
\text { L IABILITI S(B) }\end{array}$ & $\mathbf{2 5 , 6 4 , 2 0 0}$ & $\mathbf{2 8 , 0 2 , 7 6 0}$ & & \\
\hline Working Cap ital (A-B) & $27,59,015$ & $9,66,483$ & $3,74,350$ & $21,66,882$ \\
\hline $\begin{array}{l}\text { Net increase Working } \\
\text { Capital }\end{array}$ & & $17,92,532$ & $17,92,532$ & \\
\hline T Or AL & $27,59,015$ & $27,59,015$ & $21,66,882$ & $21,66,882$ \\
\hline
\end{tabular}

Source: Comp iled from Audited Annual Report of DE WAN HOUSING finance LOAN CORPORAT ION Limited.

\section{RESULTS}

The finding revealed from the analysis of the data in the previous chapter is summarized as below [2 ],[ 4],[6] * The current ratio is changing continuously and it was low (1.13) during the period 2014-2015 and it increase to (3.16) during 2012-2013. As analyzed the ratio was less.

* The liquid ratio is changing continuously and it was low (0.30) during the period 2016-2017 and it increase to (2.14) during 2013-2014. As analyzed the ratio was can see that in 2013-2014 the liquid ratio was very high because of high .

* The debt equity ratio is changing continuously and it was low (1.52) during the period 2013-2014 and it increase to (2.48) in the year 2014-2015. As analyzed the debt equity ratio was very less due to delay payment by the receiver.

- The gross profit ratio is changing continuously and it was low (2.12) during the period 2015-2016 and it increase to (3.309) during the period 2012-2013. As we compare the gross profit ratios of every year it can be noticed that in 2016-2017 it is very high because of high.

* The net profit ratio is changing continuously and it was low (1.23) during the period 2015-2016 and it increase to (3.3) during the period 2013-2014. As comparing the net profit ratios of the last five year.

* The operating ratio is changing continuously and it was low (94.3) during the period 2016-2017 and it increase to (104.24). As we analyzed the operating ratios was not done properly during the year 2016-2017 .

* The capital turnover ratio is changing continuously and it was low (0.3) during the period 2015-2016 and it increase to (6.95) during the period 2007-2008. As we analyzed capital turnover ratios is due to unstabilit.

* The stock turnover ratio is changing continuously and it was low (5.06) during the period 2010-2011 and it increase to (55.35) during the period 2011-2012. The company has to take adequate step to increase the inventory level in the proportions to increasing sale.

* The working capital ratio is changing continuously and it was low (0.16) during the period and it increase to (25.76) during the period 2016-2017. As we compared the working capital turnover ratios in the year 2016-2017 was high.

\section{CONCLUSION}

The objective of working capital administration is to deal with the organizations current resources and current liabilities so that a palatable degree of working capital is kept up the significance of working capital oversaw is reflected supervisors spend an in that the fund directors invest a lot of energy dealing with the present resources and current liabilities. Masterminding short group financing arranging positive credit terms controlling the development of money overseeing the record receivable and observing the venture expend a lot of time for the fund supervisors. Each Business Firm Needs To Keep Up A Sufficient Degree Of Working Money To Maintain The Business Easily Without Money Crunch. The Present Investigation Has Demonstrated That The Working Capital Position Of This Organization Is In An Acceptable Position And There Is An Expanding Pattern For The Future Time Frame. [1],[3],[5]

\section{REFERENCES}

1) BharthVajan R., Ramachandran S.,Psychographic dimensions of training,2016,International Journal of Pharmacy and Technology,V-8,I-4,P-23727-23729

2) Balakrishnan P., Bharthvajan R.,A study on human resource planning in hospitals in Chennai City,2014,International Journal of Applied Engineering

Research,V-9,I-22,P-7503-7507 
3) Priyadarsini P., Bharthvajan R.,Role of emotional intelligence training programme in reducing the stress of the nurses,2014,International Journal of Applied Engineering Research,V-9,I-22,P-7411-7421

4) Kerinab Beenu G., Bharthvajan R.,Empirical analysis on the cosmetic buying behavior of young women in South India,2014,International Journal of Applied Engineering Research,V-9,I-22,P-7361-7366

5) Balakrishnan P., Bharthvajan R.,Whistling in the wind,2014,International Journal of Applied Engineering Research,V-9,I-22,P-7586-7593

6) Krishnan B., Peter M.,Health hazards of Indian Bpo employee-an alarming issue,2014,International Journal of Applied Engineering Research,V-9,I-22,P-7336-7341

7) Kerinab Beenu G.H., Peter M.,Role of insurance in economic development,2014,International Journal of Applied Engineering Research,V-9,I-22,P-7532-7539

8) Balakrishnan P., Peter M., Priyadarsini P.,Efficiency of safety measures for wellbeing of employees in manufacturing industry,2014,International Journal of Applied Engineering Research,V-9,I-22,P-7376-7382

9) Anbarasi M., Praveen Kumar S.,Online sales promotions of herbal products and its effectiveness towards tanisha.com,2019, Indian Journal of Public Health Research and Development,V-10,I-1,P-195-200

10) Anbarasi M., Praveen Kumar S., Various online marketing and promotions strategies to improve the validation towards the organic products in the pharmaceutical sectors,2019,Indian Journal of Public Health Research and Development,V-10,I-1,P-263-269

11) Loganathan R., Praveen Kumar S.,Grievance handling a key factor for solving issues of employees in an organization,2014,International Journal of Applied Engineering Research,V-9,I-22,P-7483-7491

12) Loganathan R., Praveen Kumar S.,Study on preference of private label brands in super and Hypermarkets,2014,International Journal of Applied Engineering Research,V-9,I-22,P-7327-7335

13) Smitha M., Praveen Kumar S.,Understanding stress and its managementamong the nurses in Chennai city,2014,International Journal of Applied Engineering Research,V-9,I-22,P-7560-7565

14) Kerinab Beenu G.H., Praveen Kumar S.,A study on the investmen behavior of Chennai investors in mutual fund schemes,2014,International Journal of Applied Engineering Research,V-9,I-22,P-7520-7525

15) Loganathan R., Praveen Kumar S.,Retention strategies key for organizational productivity,2014,International Journal of Applied Engineering Research,V-9,I-22,P-7443-7447

16) Pavithra J., Ganesan M., Brindha G.,State wise analysis of microfinance sector in India,2016,International Journal of Pharmacy and Technology,V-8,I-4,P-23417-23432

17) Pavithra J., Ganesan M.,A comparative study on microfinance in India and abroad,2016,International Journal of Applied Business and Economic Research,V-14,I-8,P-5471-5476

18) Pavithra J., Ganesan M.,A study on awareness and impact of micro-financial schemes,2016,International Journal of Applied Business and Economic Research,V-14,I-8,P-5449-5460

19) Senthilmurugan P., Pavithra J.,Consumer preference towards organised retailing with reference to Big Bazaar,2014,International Journal of Applied Engineering Research,V-9,I-22,P-7469-7475

20) Senthilmurugan P., Pavithra J.,Implication of social media marketing in growing healthcare industry,2014,International Journal of Applied Engineering Research,V-9,I-22,P-7448-7456

21) Loganathan R., Pavithra J.,Consumer perception towards private label brand over other brands in super markets and hypermarkets,2014,International Journal of Applied Engineering Research,V-9,I-22,P-7355-7360

22) Kerinab Beenu G., Pavithra J.,Tradeâ€"off between liquidity and profitability in logistics industry,2014,International Journal of Applied Engineering Research,V-9,I-22,P-7398-7401

23) Kerinab Beenu G., Pavithra J.,A study on the prospective consumerâ€ $€^{\mathrm{TM}_{S}}$ perception towards utility cars in Chennai city,2014,International Journal of Applied Engineering Research,V-9,I-22,P-7526-7531

24) Pavithra J., Dilli Babu P., Ambuli T.V.,A study on budgetary control at Maruti Service Masters, Chennai,2014,International Journal of Applied Business and Economic Research,V-12,I-2,P-151-161

25) Pavithra J., Dilli Babu P., Ambuli T.V.,A study on customer satisfaction of retro Garments Pvt Ltd, Chennai,2014,International Journal of Applied Business and Economic Research,V-12,I-2,P-381-391

26) Kerinab Beenu G.H., Pavithra J., Senthilmurugan P.,A study on the influence of promotional activities for TATA ARIA among consumers in Chennai,2014,International Journal of Applied Engineering Research,V-9,I-22,P-7572-7578

27) Vijayaragavan S.P.,An investigative expert that's general FBG sensors,International Journal of Mechanical Engineering and Technology,V-8,I-8,PP-1500-1505,Y-2017
28) Vijayaragavan S.P.,Equalization routing protocol for Wi-Fi sensor strategy,International Journal of Mechanical Engineering and Technology,V-8,I-8,PP-1662-1666,Y-2017

29) Karthik B., Kiran Kumar T.V.U., Vijayaragavan P., Bharath Kumaran E.,Design of a digital PLL using 0.35 $\hat{\mathrm{I}}^{1} / 4 \mathrm{~m}$ CMOS technology,Middle East Journal of Scientific Research,V-18,I-12,PP-1803-1806,Y-2013

30) Kanniga E., Selvaramarathnam K., Sundararajan M.,Kandigital bike operating system,Middle - East Journal of Scientific Research,V

31) Jasmin M., Vigneshwaran T., Beulah Hemalatha S.,Design of power aware on chip embedded memory based FSM encoding in FPGA,International Journal of Applied Engineering Research,V-10,I-2,PP-4487-4496,Y-2015

32) Jasmin M.,Optimization techniques for low power VLSI circuits,Middle East Journal of Scientific Research,V-20,I-9,PP-1082-1087,Y-2014

33) Jasmin M., Vigneswaran T.,Fuzzy controller for error control of on - Chip communication,2017 International Conference on Algorithms, Methodology, Models and Applications in Emerging Technologies, ICAMMAET 2017,V-2017-January,I-,PP-1-5,Y-2017

\section{AUTHORS PROFILE}

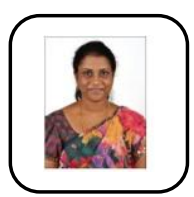

Magdalene Peter, Assistant Professor, Department of MBA,Bharath institute of Higher Education \& Research,Tamilnadu,India

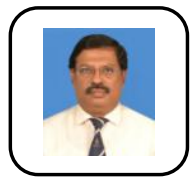

Mr. R. Ravimohan, Assistant Professor, Department of MBA,Bharath institute of Higher Education \& Research,Tamilnadu,India

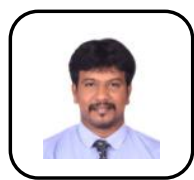

S.Venkatraman, Department of Civil,,Bharath institute of Higher Education \& Research,Tamilnadu,India Email: mailmagik@yahoo.com 